\title{
Association of perioperative intravenous fluid strategy with acute kidney injury following off-pump coronary artery bypass surgery
}

\author{
Fu-Shan Xue*, Gao-Pu Liu and Rui-Ping Li \\ See related research by Kim et al., http://www.ccforum.com/content/19/1/350
}

In the nonrandomized observational study by Kim et al. [1] evaluating association of perioperative intravenous fluid strategy with acute kidney injury (AKI) following off-pump coronary artery bypass surgery, the cumulative amount of intravenous fluids received during surgery and in the immediate postoperative period was significantly different between control and renal protective fluid management groups. We are very interested in knowing whether the serum creatinine $(\mathrm{sCr})$ levels used for diagnosis of postoperative AKI in this study had been corrected based on perioperative fluid balance.

Moore et al. [2] validate that not adjusting $\mathrm{sCr}$ levels for fluid balance may underestimate the incidence of AKI and confuse association of AKI with postoperative outcomes in cardiac surgery patients. Furthermore, we were not provided with details of intraoperative hemodynamics instability and drug administration. It has been shown that intraoperative systolic blood pressure decrease relative to baseline is independently associated with AKI after cardiac surgery $[3,4]$. Similarly, intraoperative uses of inotropes, vasopressors, and diuretics are also attributable to the development of AKI after cardiac surgery [5].

Finally, increases in $\mathrm{sCr}$ and AKI 7 days after surgery are probably subjected to confounding postoperative events, such as low cardiac output syndrome, anemia, hypoalbuminemia, reoperation for bleeding, blood transfusion, sepsis, etc. Also, the postoperative events mentioned above can significantly affect clinical outcomes of patients, for example the extubation time, duration of hospital stay, and mortality. However, it was unclear

\footnotetext{
*Correspondence: xuefushan@aliyun.com

Department of Anesthesiology, Plastic Surgery Hospital, Chinese Academy of Medical Sciences and Peking Union Medical College, 33 Ba-Da-Chu Road, Shi-Jing-Shan District, Beijing 100144, People's Republic of China
}

whether the postoperative events associated with AKI and clinical outcomes were comparable between groups or required statistical adjustments.

We thus argue that addressing these issues would further clarify the transparency of this study.

Abbreviations
AKl: Acute kidney injury; sCr: Serum creatinine.

\section{Competing interests}

The authors declare that they have no competing interests.

\section{Authors' contributions}

FSX carefully read the manuscript of Kim et al., analyzed their methods and data, suggested comment points, and drafted this manuscript, and is responsible for this manuscript. GPL carefully read the manuscript of Kim et al., analyzed their methods and data, and revised the comment points and this manuscript. RPL read the manuscript of Kim et al., helped to analyze their methods and data, and revised the comment points. All authors read and approved the final manuscript.

Published online: 24 November 2015

\section{References}

1. Kim JY, Joung KW, Kim KM, Kim MJ, Kim JB, Jung SH, et al. Relationship between a perioperative intravenous fluid administration strategy and acute kidney injury following off-pump coronary artery bypass surgery. Crit Care. 2015;19:350

2. Moore E, Tobin A, Reid D, Santamaria J, Paul E, Bellomo R. The impact of fluid balance on the detection, classification and outcome of acute kidney injury after cardiac surgery. J Cardiothorac Vasc Anesth. 2015;29:1229-35.

3. Aronson S, Phillips-Bute B, Stafford-Smith M, Fontes M, Gaca J, Mathew JP, et al. The association of postcardiac surgery acute kidney injury with intraoperative systolic blood pressure hypotension. Anesthesiol Res Pract. 2013;2013:174091.

4. Kanji HD, Schulze CJ, Hervas-Malo M, Wang P, Ross DB, Zibdawi M, et al. Difference between pre-operative and cardiopulmonary bypass mean arterial pressure is independently associated with early cardiac surgery-associated acute kidney injury. J Cardiothorac Surg. 2010;5:71.

5. Vives M, Wijeysundera D, Marczin N, Monederoe P, Raof V. Cardiac surgery-associated acute kidney injury. Interact Cardiovasc Thorac Surg. 2014;18:637-45.

\section{Biomed Central}

(c) 2015 Xue et al. Open Access This article is distributed under the terms of the Creative Commons Attribution 4.0 International License (http://creativecommons.org/licenses/by/4.0/, which permits unrestricted use, distribution, and reproduction in any medium, provided you give appropriate credit to the original author(s) and the source, provide a link to the Creative Commons license, and indicate if changes were made. The Creative Commons Public Domain Dedication waiver (http://creativecommons.org/publicdomain/zero/1.0/) applies to the data made available in this article, unless otherwise stated. 